\title{
The germination success of the cut seeds of Eugenia pyriformis depends on their size and origin ${ }^{1}$
}

\author{
Juliana Sakagawa Prataviera², Edmir Vicente Lamarca², \\ Carmen Cinira Teixeira², Claudio José Barbedo2*
}

\begin{abstract}
Seeds of Eugenia pyriformis may produce several seedlings after cutting. Both the type of cutting and the size of the seed can determine the success in obtaining new seedlings. The size of the seeds is dependent on both the number of seeds per fruit and the conditions in which seeds develop, as well as the biometric characteristics of these seeds obtained from different regions and seasons. The seeds from each origin were evaluated in length, width, thickness, water content and dry mass, as well as the average number of seeds per fruit. From one of the regions, seeds were grouped according to the number of seeds per fruit and also according to their size, and then cut into two and four parts, and then analyzed for the fragments germination. The results demonstrated the high capacity of these seed fragments to produce new seedlings, but the capability reduces with the reduction in seed size. This size depends not only on the number of seeds per fruit, but also on the region and the period of the seed production.
\end{abstract}

Index terms: germination, seed cutting, Myrtaceae, uvaia.

\section{O sucesso da germinação de sementes fracionadas de Eugenia pyriformis depende do seu tamanho e da sua origem}

\begin{abstract}
RESUMO - Uma semente de uvaieira (Eugenia pyriformis) pode produzir várias plântulas quando fracionada. A posição do corte e o tamanho da semente influenciam o sucesso da obtenção de novas plântulas. O número de sementes por fruto e as condições nas quais as sementes se desenvolvem podem promover diferenças nesse tamanho. No presente trabalho foram analisados o grau de influência do número de sementes por fruto sobre a capacidade das sementes de uvaieira em germinar após fracionamento e os aspectos biométricos de sementes de uvaieira obtidas em diferentes regiões e épocas. As sementes de cada origem foram avaliadas quanto ao comprimento, largura, espessura, conteúdo de massa fresca e seca e teor de água. De uma das regiões, sementes foram agrupadas segundo a quantidade de sementes por fruto e também segundo seu tamanho e, a seguir, foram fracionadas em duas e quatro partes e analisadas quanto à capacidade germinativa dos fragmentos obtidos. Os resultados demonstraram a elevada capacidade dos fragmentos dessas sementes em formar novas plântulas, mas tal capacidade reduz concomitante à redução no tamanho da semente. Esse tamanho depende não apenas do número de sementes por fruto, mas também da região e da época de produção das sementes.
\end{abstract}

Termos para indexação: germinação, fracionamento de semente, Myrtaceae, uvaia.

\section{Introduction}

Uvaia (Eugenia pyriformis Cambess - Myrtaceae) produces fruits which are of great marketing, gastronomic and pharmacological value and are native of Brazil (Stieven et al., 2009; Ramirez et al., 2012; Lamarca et al., 2013a), with great potential for economic exploitation. However, this exploitation still depends on technology development for a large-scale production, which has limitations starting at the commercial orchards installation. The seedling production of this species is currently low due to, among other factors, the lack of sufficient amount of seeds, for there are few plants producing fruits, few fruits per plant and few seeds per fruit (Silva et al., 2005). The number of seeds per fruit is variable, but generally does not exceed four units (Justo et al., 2007). Therefore, to increase the cuttings production there is the need to deploy orchards producing seeds and/or to maximize the use of seeds produced.

Studies have demonstrated the possibility of having several seedlings from a single uvaia seed because, although

${ }^{1}$ Submitted on 10/07/2014. Accepted for publication on 02/12/2015.

${ }^{2}$ Instituto de Botânica, Núcleo de Pesquisa em Sementes, Caixa Postal, 68041, 04301012 - São Paulo, SP, Brasil.

*Corresponding author < claudio.barbedo@pesquisador.cnpq.br> 
monoembryonic, such seed has great potential in producing seedlings after being cut (Delgado et al., 2010; Teixeira and Barbedo, 2012). This potential suggests the presence of meristematic tissues capable of further differentiation, including in new embryos (Delgado et al., 2010). In fact, in general, the embryo has meristematic toti or pluripotent cells, offering all the information needed to grow and give rise to a mature plant (Marcos-Filho, 2005; Batygina and Vinogradova, 2007). In uvaia, this characteristic was described ten years ago and has been studied since then.

Non fractioned uvaia seed produces, as a rule, a single root and single seedlings. It was found, for example, that seeds fractioned into two parts produce two independent root systems (one in each resultant fraction), each one generating a new seedling. This would suggest that there is a potential stimulating effect generated by the cut however, curiously, there is hardly any formation of two root systems in the same fraction, suggesting a method of inhibiting a second germination after the beginning of the first seedling development (Amador and Barbedo, 2011). It was also found that both the cutting positions as well as the size of the seed influence the success of obtaining young seedlings. Therefore, when increasing the number of cuts in the seeds, only the largest ones proved to be able to continue producing young seedlings (Silva et al., 2005; Amador and Barbedo, 2011; Teixeira and Barbedo, 2012). Therefore the resulting mass after fractioning seems to affect the success in the production of seedlings per seed.

One of the factors that influence the size of uvaia seeds is the number of seeds per fruit, for seeds are smaller when more numerous per fruit (Justo et al., 2007). The conditions under which seeds develop can also promote differences in the size of seeds produced. Studies show that water availability and thermal variations, for example, may contribute to the variability of physical aspects such as the size and weight of fruits and seeds, among individuals or populations of the same species (Daws et al., 2004, 2006; Santos et al., 2009; Andrade et al., 2010; Joët et al., 2013). Specifically for uvaia, environmental conditions during seed formation may exert great influence on their various characteristics, but did not assess such influence on the size (Lamarca et al., 2013b). There is no description in literature on uvaia seed size variations according to its origin, nor variations in the potential of these seeds in producing new seedlings after cutting, arising from the size and number of seeds per fruit.

In the present study, the degree of influence of the number of uvaia seeds per fruit on seed germinability after cutting were analyzed, as well as their biometric aspects obtained in different regions and seasons.

\section{Material and Methods}

Origin of seeds: uvaia seeds were obtained from freshly dispersed ripe fruits, according to the maturation and dispersal information from Lamarca et al. (2013b). Fruits were collected from 10 different regions, as described in detail in Table 1. Abbreviations have been adopted, according to the area and period or elevation, as follows: Ribeirão Preto (RIB), Lavras (LAV), São Bento do Sapucaí (SBS), Campinas (CAM), Jumirim (JUM), São Paulo (SPA), Ibiúna (IBI), São Bernardo do Campo (SBC), Itaberá (ITA) and Pariquera-Açú (PAR). In four of those regions (CAM, SPA, IBI and SBC) seeds were obtained from the same plants in two years, identified as 1 and 2 and, SBS from three different elevations, indicated by 1, 2 and 3. Each collecting according to the period and region or region and elevation, was seen as a different origin of seeds.

In the period of the species maximum flowering, of each origin, tree inflorescences that had most of the flowers in anthesis were marked. From weather stations, located close to the collection areas, daily rainfall data were obtained $(\mathrm{mm})$, as well as maximum and minimum air temperatures $\left({ }^{\circ} \mathrm{C}\right)$. The data were provided by the Campinas Agronomic Institute, Federal University of Lavras and the Astronomical and Geophysical Institute of São Paulo University. At the period between flowering and seed dispersal the accumulated precipitation $(\mathrm{mm})$ and accumulated degree-days $\left({ }^{\circ} \mathrm{C}\right.$.day), were calculated according to the equations proposed by Villa Nova et al. (1972), taking into consideration the basic temperature of $10{ }^{\circ} \mathrm{C}$ (Pedro Junior et al., 1977).

The germinating capacity analysis after cutting according to size and number of seeds per fruit: SPA2 seeds were grouped among those from fruits containing a single seed, fruits containing two seeds and fruits containing three or more seeds. Each group of seed samples was evaluated per size, three orthogonal axes measures being taken, using digital calipers with $0.01 \mathrm{~mm}$ accuracy. The largest seed size axis was considered to be its length, perpendicular to the major axis length regarded as width, and the axis perpendicular to the previous two as its thickness.

In a first experiment, seeds of each group were divided into three groups, each receiving different cutting treatments: a) whole seeds (without cutting), b) seeds cut in its middle and c) seeds cut into four parts. Therefore, we obtained a $3 \times 3$ factorial design (number of seeds per fruit $\mathrm{x}$ type of cutting) in a completely randomized design and four replications of 16 seeds in each test.

In a second experiment, the seeds from fruits with one or two seeds were separated according to their size, small and large, keeping track of their origin (number of seeds per fruit). Therefore, four groups of seeds were obtained, according to 
origin and size: large seeds from fruits with one seed (LGF1), large seeds from fruits with two seeds (LGF2), small seeds from fruits with one seed (SSF1) and small seeds from fruits with two seeds (SSF2). Seeds were also cut as described in the previous experiment, obtaining a 4 x 3 factorial (seed origin $\mathrm{x}$ fractionation type), with four replicates of 16 seeds.

Table 1. Uvaia seeds origin. Geographic location, Köppen climate classification, maturation cycle (period between flowering and dispersion) and collection sites meteorological data during the maturation cycle. Min: minimum temperature; Max: maximum temperature; Degree-days; Rain: accumulated rain precipitation; WC: seed water content $(\%$ wet basis) at the time of dispersion.

\begin{tabular}{|c|c|c|c|c|c|}
\hline Seed origin & $\begin{array}{l}\text { Maturation period } \\
\text { (maturation cycle ) }\end{array}$ & $\begin{array}{c}\text { Min - Max } \\
\left({ }^{\circ} \mathrm{C}\right)\end{array}$ & $\begin{array}{l}\text { Degree-day } \\
\left({ }^{\circ} \mathrm{C} \text { day }\right)\end{array}$ & $\begin{array}{l}\text { Rain } \\
(\mathrm{mm})\end{array}$ & $\begin{array}{l}\mathrm{WC} \\
(\%)\end{array}$ \\
\hline $\begin{array}{l}\text { RIB - Ribeirão Preto, SP } \\
\left(21^{\circ} 10^{\prime} \mathrm{S}, 47^{\circ} 52^{\prime} \mathrm{O}, 593 \mathrm{~m} \text {; Cwa) }\right.\end{array}$ & $\begin{array}{c}14 / 08 / 10-17 / 09 / 10 \\
(34 \text { days })\end{array}$ & $14-31$ & 440 & 6.9 & 62.8 \\
\hline $\begin{array}{l}\text { LAV - Lavras, MG } \\
\left(21^{\circ} 13^{\prime} \mathrm{S}, 44^{\circ} 58^{\prime} \mathrm{O}, 949 \mathrm{~m} \text {; Cwa) }\right.\end{array}$ & $\begin{array}{c}15 / 08 / 10-25 / 09 / 10 \\
\text { (41 days) }\end{array}$ & $12-28$ & 417 & 24.2 & 53.6 \\
\hline $\begin{array}{l}\text { SBS1 - São Bento do Sapucaí, SP } \\
\left(22^{\circ} 41^{\prime} \mathrm{S}, 45^{\circ} 43^{\prime} \mathrm{O}, 884 \mathrm{~m} \text {; Cfb) }\right.\end{array}$ & $\begin{array}{c}24 / 08 / 10-07 / 10 / 10 \\
\text { (44 days) }\end{array}$ & $12-27$ & 426 & 177.1 & 65.0 \\
\hline $\begin{array}{l}\text { SBS2 - São Bento do Sapucaí, SP } \\
\left(22^{\circ} 41^{\prime} \mathrm{S}, 45^{\circ} 45^{\prime} \mathrm{O}, 1022 \mathrm{~m} \text {; Cfb }\right)\end{array}$ & $\begin{array}{c}26 / 08 / 10-15 / 10 / 10 \\
\text { (50 days) }\end{array}$ & $11-26$ & 448 & 177.1 & 57.3 \\
\hline $\begin{array}{l}\text { SBS3 - São Bento do Sapucaí, SP } \\
\left(22^{\circ} 41^{\prime} \mathrm{S}, 45^{\circ} 46^{\prime} \mathrm{O}, 1121 \mathrm{~m} \text {; Cfb) }\right.\end{array}$ & $\begin{array}{l}26 / 08 / 10-21 / 10 / 10 \\
\text { (56 days) }\end{array}$ & $11-26$ & 472 & 252.4 & 53.0 \\
\hline $\begin{array}{l}\text { CAM1 - Campinas, SP } \\
\left(22^{\circ} 52^{\prime} \mathrm{S}, 47^{\circ} 04^{\prime} \mathrm{O}, 645 \mathrm{~m} \text {; Cwa) }\right.\end{array}$ & $\begin{array}{l}\text { 10/08/10 - 19/09/10 } \\
\text { (40 days) }\end{array}$ & $14-28$ & 451 & 6.3 & 55.4 \\
\hline $\begin{array}{l}\text { CAM2 - Campinas, SP } \\
\left(22^{\circ} 52^{\prime} \mathrm{S}, 47^{\circ} 04^{\prime} \mathrm{O}, 645 \mathrm{~m} \text {; Cwa) }\right.\end{array}$ & $\begin{array}{c}\text { 06/08/11 - 14/09/11 } \\
\text { (39 days) }\end{array}$ & $14-28$ & 442 & 36.7 & 58.9 \\
\hline $\begin{array}{l}\text { JUM - Jumirim, SP } \\
\left(22^{\circ} 05^{\prime} \mathrm{S}, 47^{\circ} 47^{\prime} \mathrm{O}, 540 \mathrm{~m} \text {; Cwa) }\right.\end{array}$ & $\begin{array}{l}\text { 05/08/10 - 19/09/10 } \\
\text { (45 days) }\end{array}$ & $12-29$ & 481 & 12.6 & 59.8 \\
\hline $\begin{array}{l}\text { SPA1 - São Paulo, SP } \\
\left(23^{\circ} 38^{\prime} \mathrm{S}, 46^{\circ} 37^{\prime} \mathrm{O}, 785 \mathrm{~m} \text {; Cwb) }\right.\end{array}$ & $\begin{array}{l}\text { 26/08/10 }-09 / 10 / 10 \\
\text { (44 days) }\end{array}$ & $14-25$ & 428 & 128.8 & 64.5 \\
\hline $\begin{array}{l}\text { SPA2 - São Paulo, SP } \\
\left(23^{\circ} 38^{\prime} \mathrm{S}, 46^{\circ} 37^{\prime} \mathrm{O}, 785 \text { m; Cwb) }\right.\end{array}$ & $\begin{array}{l}31 / 08 / 11-10 / 10 / 11 \\
\quad(40 \text { days })\end{array}$ & $13-25$ & 374 & 99.1 & 66.6 \\
\hline $\begin{array}{l}\text { IBI1 - Ibiúna, SP } \\
\left(23^{\circ} 39^{\prime} \mathrm{S}, 47^{\circ} 09^{\prime} \mathrm{O}, 917 \mathrm{~m} ; \mathrm{Cfb}\right)\end{array}$ & $\begin{array}{c}12 / 09 / 10-23 / 10 / 10 \\
(41 \text { days })\end{array}$ & $12-27$ & 413 & 123.6 & 61.6 \\
\hline $\begin{array}{l}\text { IBI2 - Ibiúna, SP } \\
\left(23^{\circ} 39^{\prime} \mathrm{S}, 47^{\circ} 09^{\prime} \mathrm{O}, 917 \text { m; Cfb) }\right.\end{array}$ & $\begin{array}{l}\text { 04/09/11 - 12/10/11 } \\
\text { (38 days) }\end{array}$ & $10-29$ & 380 & 103.2 & 62.3 \\
\hline $\begin{array}{l}\text { SBC1 - São Bernardo do Campo, SP } \\
\left(23^{\circ} 42^{\prime} \mathrm{S}, 46^{\circ} 33^{\prime} \mathrm{O}, 786 \mathrm{~m} \text {; Cwb) }\right.\end{array}$ & $\begin{array}{l}\text { 16/08/10 - 03/10/10 } \\
\text { (48 days) }\end{array}$ & $13-25$ & 458 & 104.3 & 56.3 \\
\hline $\begin{array}{l}\text { SBC2 - São Bernardo do Campo, SP } \\
\left(23^{\circ} 42^{\prime} \mathrm{S}, 46^{\circ} 33^{\prime} \mathrm{O}, 786 \mathrm{~m} \text {; Cwb) }\right.\end{array}$ & $\begin{array}{l}\text { 16/08/11 - 01/10/11 } \\
\text { (46 days) }\end{array}$ & $13-25$ & 406 & 68.5 & 57.9 \\
\hline $\begin{array}{l}\text { ITA - Itaberá, SP } \\
\left(23^{\circ} 52^{\prime} \mathrm{S}, 49^{\circ} 06^{\prime} \mathrm{O}, 683 \mathrm{~m} \text {; Cfa }\right)\end{array}$ & $\begin{array}{l}\text { 17/08/10 - 23/09/10 } \\
\text { (37 days) }\end{array}$ & $11-26$ & 341 & 1.8 & 65.7 \\
\hline $\begin{array}{l}\text { PAR - Pariquera-Açú, SP } \\
\left(24^{\circ} 37^{\prime} \mathrm{S}, 47^{\circ} 53^{\prime} \mathrm{O}, 28 \mathrm{~m} \text {; Af) }\right.\end{array}$ & $\begin{array}{c}23 / 08 / 10-11 / 10 / 10 \\
(49 \text { days })\end{array}$ & $15-25$ & 501 & 87.4 & 59.6 \\
\hline
\end{tabular}

Seeds and seed fractions were placed in transparent, colorless plastic boxes (gerbox type) filled with expanded vermiculite of medium particle size, saturated with $70 \mathrm{~mL}$ tap water and placed in a growth chamber at $25^{\circ} \mathrm{C}$, with constant light and $100 \%$ relative humidity. The number of seeds or seed fractions which produced normal seedlings was registered (Delgado and Barbedo, 2007) to calculate germination and seeds issuing primary root with at least $2 \mathrm{~cm}$, for germinable seeds evaluation.

The evaluations were performed every 5 days, until there were no more new roots for 30 consecutive days. The final accounting of germination and germinated seeds, for cut seeds, were the number of fractions with normal seedlings or protruded roots, respectivelly, related to the total number 
of seeds. Data were subjected to the variance analysis and averages were compared by the Tukey test with $5 \%$ probability (Santana and Ranal, 2004).

Biometrics and germination of seeds from different origins: at the end of the period of fruit formation and maturation, freshly dispersed ripe fruits were collected (up to 24 hours from dispersion) for seed biometric evaluations. We selected 40 fruits at random from each origin, opened them, registering the number of seeds per fruit. The seeds were then washed in water, on strainer. Once washed, we removed the excess water on its surface with filter paper. Afterwards the seeds from each origin were evaluated per length, width, thickness, as described above. Dry and fresh mass and water content were also evaluated. The fresh mass content was determined by a scale with $0.001 \mathrm{~g}$ accuracy, the results being shown in $\mathrm{g}$.seed ${ }^{-1}$; the dry mass content and the water content was determined gravimetrically by oven method at $103{ }^{\circ} \mathrm{C}$ for 17 hours with the results shown, respectively, in g. $\operatorname{seed}^{-1}$ and in $\%$ (wet basis), as described in Brasil (2009). The germination test was performed as described previously.

The experimental design was completely randomized with four replications of 10 seeds. The data obtained were subjected to the variance analysis (F test), at 5\% level. When relevant, the averages were compared by the Tukey test, also at 5\% (Santana and Ranal, 2004). Later, we calculated simple correlation coefficients for all combinations between the meteorological data and biometric data of the seeds and the significance was determined by t test with $5 \%$ probability.

\section{Results and Discussion}

The seed dimensions according to the number of seeds per fruit (Figure 1A) showed that the greater the number of seeds per fruit, the smaller the final size of each seed, as was also observed by Justo et al. (2007). The germination potential was high for seeds from all sources (Figure 1), reaching values above $200 \%$ of germinable seeds, when cut into four parts (Figure 1C). However, it was found that the number of seeds contained in the fruit is related to the germination capacity, specifically when there are three or more seeds per fruit, and also when more than one cutting is performed. One explanation for this difference would be the fact that, as described above, a larger number of seeds per fruit results in smaller seeds and the seed mass are directly related to the number of cutting, capable of ensuring the formation of new seedlings (Silva et al., 2003). Therefore, it would be expected that the greater the number of seeds per fruit, the lower the germination capacity of these seeds. This was observed when comparing seeds from fruits with three or more seeds, to fruits with one or two seeds, however not when comparing the last two ones. This could be due to the variation in seed size of these two sources, which was high. These are the most frequent categories, specifically the fruits with two seeds, which correspond to $81 \%$ of the fruits (Andrade and Ferreira, 2000).

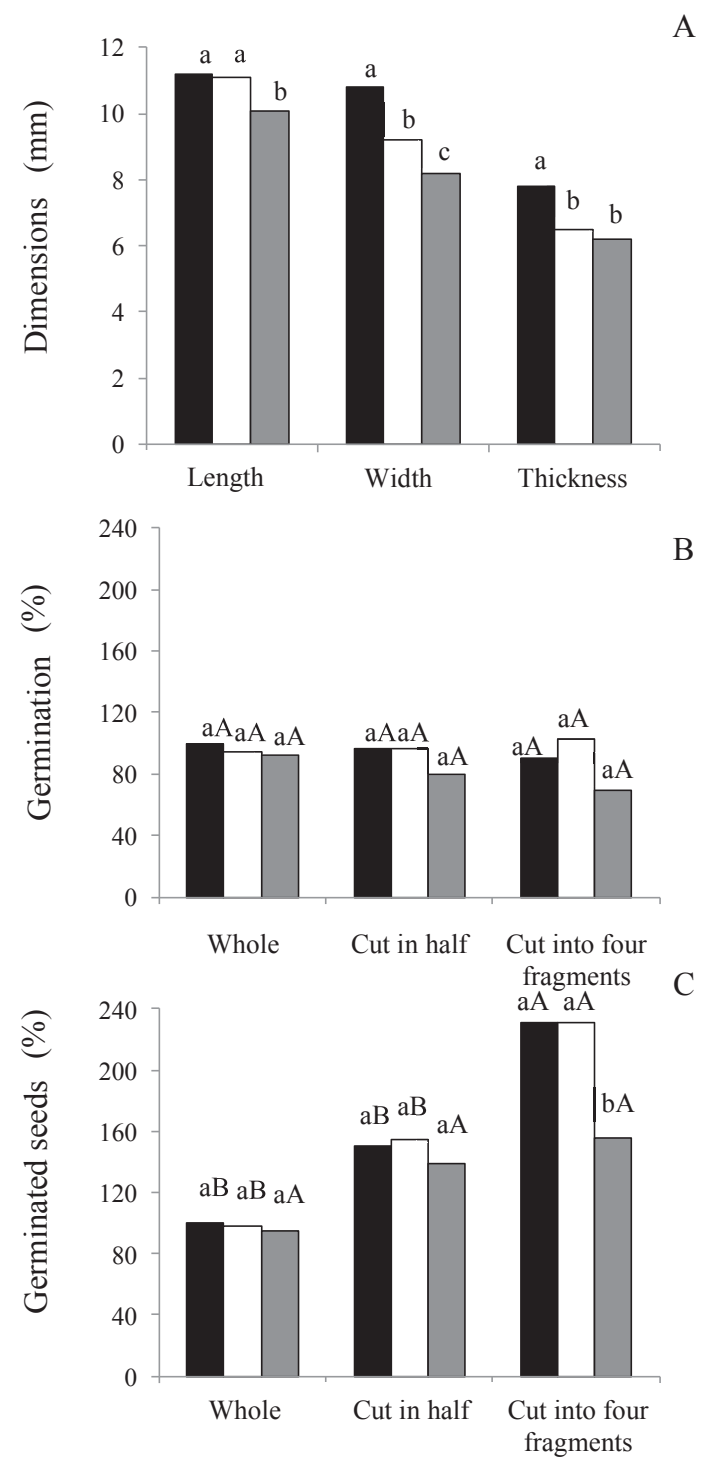

Figure 1. Uvaia seed size (A) germination (B) and germinated seeds (C) according to the number of seeds per fruit and type of cutting. Columns in black: fruit with one seed; in white: with two seeds; gray: three or more seeds. Columns with the same letter (lowercase comparing number of seeds per fruit, upper case comparing cutting) do not differ among them (Tukey, 5\%).

The size variation in the seeds of these two groups was evident in the second experiment, in which seeds were visually divided between large and small. Seeds of different 
sizes within the same sub category were obtained (Figure $2 \mathrm{~A}$ ). The results of germination of these subgroups showed that seed size has greater effect on germination after cutting than the amount of seeds per fruit. Within the same category, large seeds germinated more than the small ones (Figure 2).
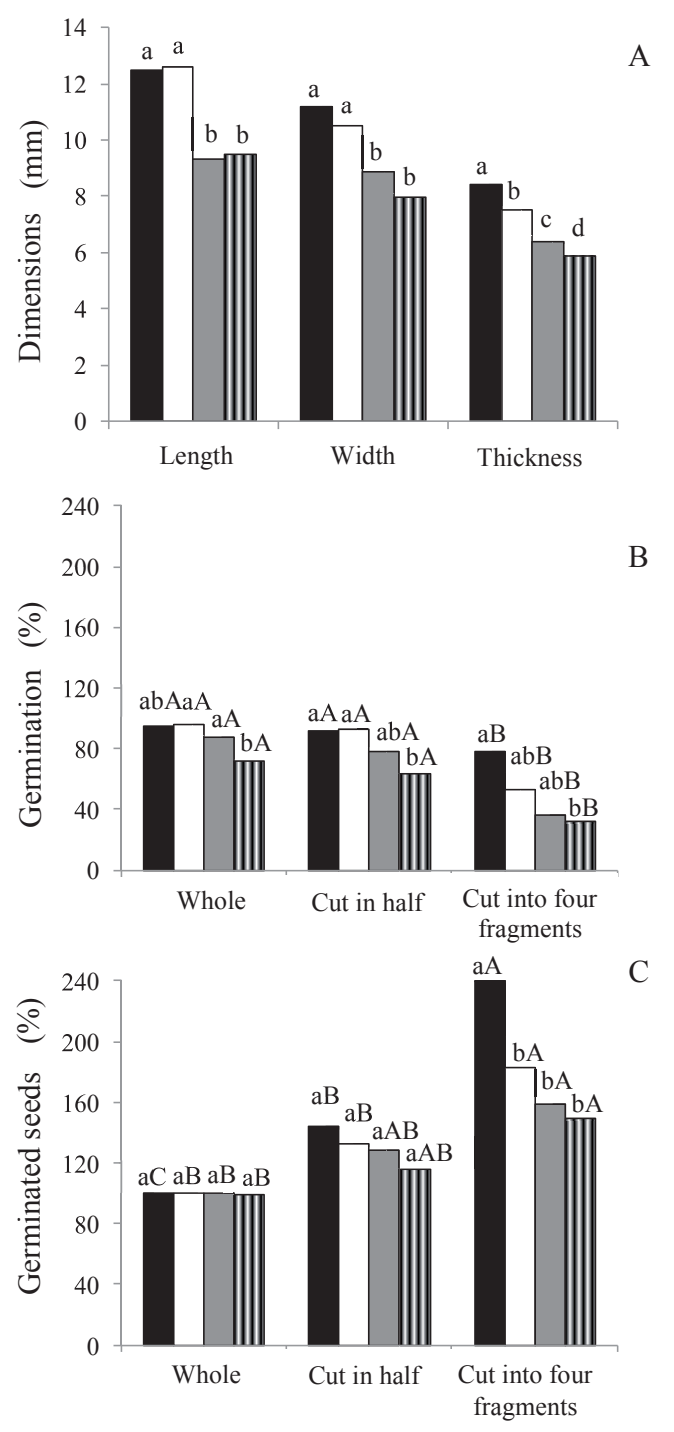

Figure 2. Uvaia seed size (A) germination (B) and germinated seeds (C) according to the number of seeds per fruit and type of cutting. Columns in black: large seeds, fruit with one seed; in white: large seeds, fruits with two seeds; gray: small seeds, fruit with one seed; stripes: small seeds, fruits with two seeds. Columns with the same letter (lowercase comparing size and number of seeds per fruit, upper case comparing cutting type) do not differ among them (Tukey, 5\%).
Cutting small seeds SSF1 and SSF2 showed that there is a higher limitation on the plant growth than in the root production. This could be due to: 1) the seed fragmentation reduces the reserves amount that, in the small ones, can become insufficient for the seedling, root and shoot growth, similar to the described in previous studies (Silva et al., 2003; Teixeira and Barbedo, 2012); 2) the distance between the germination region end and its opposite is higher in the larger seeds than on the smaller ones. In this case a possible inhibitory effect, caused by the first germination onset, preventing the totipotent cells differentiation in the opposite area, would take longer to sense in larger fragments, similar to the observed with fissured seeds (partially fractioned) (Amador and Barbedo, 2011).

The results obtained for the cut seeds of different sizes demonstrated the importance of the biometrics knowledge for a better analysis of benefits and harms of this fractionation. However, the variation in seed size not only lies in the number of seeds per fruit, but also in the region and time of seeds production. Seeds of Santa Maria, Rio Grande do Sul state, for example, showed fresh mass between 0.2 and $2.0 \mathrm{~g}$ (Andrade and Ferreira, 2000), while those from Lavras, Minas Gerais state, were between 0.5 and $2.5 \mathrm{~g}$ (Justo et al., 2007), a variation range similar to the one obtained in the present study, from 0.5 to $2.7 \mathrm{~g}$, considering ten regions and 16 different origins (Table 2).

Seeds obtained from different regions and seasons also demonstrated big changes of other biometric aspects evaluated, such as length (ranging from 8.11 to $19.21 \mathrm{~mm}$ ), width (7.11 to $16.18 \mathrm{~mm}$ ), thickness (5.28 to $13.36 \mathrm{~mm}$ ), beyond the number of seeds per fruit (which ranged from 1.08 to 1.85). The seed size (length, width and thickness) is linked to the fresh and dry mass content and water content, as there were significant correlations between these variables (Table 3). The number of seeds per fruit was always between 1 and 4, similar to the previously observed (Andrade and Ferreira, 2000; Justo et al., 2007). However, the average seeds per fruit little fluctuated, between 1.08 and 1.80 (Table 2). Considering that plants from ten different regions were analyzed, it can be assumed that the uvaia fruit produce mostly, one or two seeds. The number of seeds was negatively correlated to the length and thickness (Table 3). Therefore, when the fruit has two seeds, these are smaller than those with one seed, especially concerning length and thickness and, as seen in the previous experiment, it directly affects the seed germination capacity after fractionation.

The highest values of length, width, thickness and fresh and dry mass were from higher elevation and higher maturation cycle, SBS2 and SBS3 respectively (Tables 1 and 2). On the other side, the source that had length, width and thickness lowest values, had the highest value of seeds number per fruit, as IBI2 (Table 2). 
Table 2. Length (mm), width (mm), thickness (mm), Q (quantity of fruits ${ }^{-1}$ ), MF (fresh mass, seed.g ${ }^{-1}$ ), MS (dried mass, seed. $\mathrm{g}^{-1}$ ) and $\mathrm{G}$ (germination, \%) of uvaia seeds from different origins.

\begin{tabular}{clcccccc}
\hline Origin & Length & Width & Thickness & Q & MF & MS & G \\
\hline RIB & $14.12 \mathrm{cdef} *$ & $12.17 \mathrm{cde}$ & $8.79 \mathrm{bcde}$ & $1.18 \mathrm{ab}$ & $1.29 \mathrm{~d}$ & $0.48 \mathrm{efg}$ & $90 \mathrm{abc}$ \\
LAV & $16.06 \mathrm{abc}$ & $13.04 \mathrm{bcd}$ & $10.08 \mathrm{~b}$ & $1.33 \mathrm{ab}$ & $1.73 \mathrm{c}$ & $0.81 \mathrm{c}$ & $100 \mathrm{a}$ \\
SBS1 & $15.63 \mathrm{bcd}$ & $13.46 \mathrm{abc}$ & $9.89 \mathrm{bc}$ & $1.30 \mathrm{ab}$ & $1.06 \mathrm{def}$ & $0.37 \mathrm{~g}$ & $87 \mathrm{abc}$ \\
SBS2 & $17.74 \mathrm{ab}$ & $15.56 \mathrm{ab}$ & $12.13 \mathrm{a}$ & $1.13 \mathrm{~b}$ & $2.27 \mathrm{~b}$ & $0.97 \mathrm{~b}$ & $88 \mathrm{abc}$ \\
SBS3 & $19.21 \mathrm{a}$ & $16.18 \mathrm{a}$ & $13.36 \mathrm{a}$ & $1.25 \mathrm{ab}$ & $2.70 \mathrm{a}$ & $1.27 \mathrm{a}$ & $72 \mathrm{abcd}$ \\
CAM1 & $13.19 \mathrm{cdefg}$ & $11.05 \mathrm{cdef}$ & $8.41 \mathrm{cde}$ & $1.14 \mathrm{~b}$ & $1.08 \mathrm{def}$ & $0.48 \mathrm{efg}$ & $92 \mathrm{abc}$ \\
CAM2 & $13.45 \mathrm{cdefg}$ & $11.29 \mathrm{cdef}$ & $8.47 \mathrm{bcde}$ & $1.58 \mathrm{ab}$ & $1.26 \mathrm{~d}$ & $0.52 \mathrm{ef}$ & $85 \mathrm{abcd}$ \\
JUM & $14.85 \mathrm{bcde}$ & $12.01 \mathrm{cde}$ & $9.02 \mathrm{bcd}$ & $1.60 \mathrm{ab}$ & $1.06 \mathrm{def}$ & $0.43 \mathrm{fg}$ & $95 \mathrm{ab}$ \\
SPA1 & $11.46 \mathrm{fg}$ & $9.98 \mathrm{ef}$ & $8.02 \mathrm{de}$ & $1.48 \mathrm{ab}$ & $0.65 \mathrm{gh}$ & $0.23 \mathrm{~h}$ & $63 \mathrm{~cd}$ \\
SPA2 & $10.48 \mathrm{gh}$ & $8.99 \mathrm{fg}$ & $7.18 \mathrm{e}$ & $1.50 \mathrm{ab}$ & $0.70 \mathrm{gh}$ & $0.20 \mathrm{~h}$ & $87 \mathrm{abc}$ \\
IBI1 & $12.49 \mathrm{defg}$ & $10.46 \mathrm{def}$ & $8.77 \mathrm{bcde}$ & $1.08 \mathrm{~b}$ & $1.00 \mathrm{ef}$ & $0.39 \mathrm{~g}$ & $72 \mathrm{abcd}$ \\
IBI2 & $8.11 \mathrm{~h}$ & $7.11 \mathrm{~g}$ & $5.28 \mathrm{f}$ & $1.85 \mathrm{a}$ & $0.50 \mathrm{~h}$ & $0.19 \mathrm{~h}$ & $57 \mathrm{~d}$ \\
SBC1 & $13.25 \mathrm{cdefg}$ & $12.07 \mathrm{cde}$ & $9.40 \mathrm{bcd}$ & $1.23 \mathrm{ab}$ & $1.27 \mathrm{~d}$ & $0.56 \mathrm{e}$ & $68 \mathrm{bcd}$ \\
SBC2 & $12.13 \mathrm{efg}$ & $10.92 \mathrm{cdef}$ & $8.51 \mathrm{bcde}$ & $1.35 \mathrm{ab}$ & $0.92 \mathrm{fg}$ & $0.39 \mathrm{~g}$ & $90 \mathrm{abc}$ \\
ITA & $14.65 \mathrm{bcdef}$ & $13.17 \mathrm{bcd}$ & $9.57 \mathrm{bcd}$ & $1.18 \mathrm{ab}$ & $1.21 \mathrm{de}$ & $0.42 \mathrm{fg}$ & $78 \mathrm{abcd}$ \\
PAR & $15.60 \mathrm{bcd}$ & $13.17 \mathrm{bcd}$ & $9.60 \mathrm{bcd}$ & $1.10 \mathrm{~b}$ & $1.67 \mathrm{c}$ & $0.68 \mathrm{~d}$ & $73 \mathrm{abcd}$ \\
\hline C.V. $\%$ ) & 9.11 & 9.12 & 7.01 & 20.26 & 7.82 & 8.87 & 11.62 \\
\hline
\end{tabular}

* Averages followed by the same letter do not differ by the Tukey test, at $5 \%$.

Table 3. Simple correlation coefficients (r) between meteorological and biometric data of uvaia seed germination from different origins.

\begin{tabular}{|c|c|c|c|c|c|c|c|c|c|c|c|c|}
\hline & MIN & MAX & $\mathrm{DD}$ & RAIN & LENG & WID & THICK & NUM & FM & DM & WC & $\mathrm{G}^{13}$ \\
\hline CYCLE $^{1}$ & -0.11 & $-0.57 *$ & $0.59 *$ & $0.71^{*}$ & $0.58^{*}$ & -0.10 & $0.69 *$ & -0.25 & -0.12 & $-0.53 *$ & $0.67^{*}$ & -0.16 \\
\hline $\mathrm{MIN}^{2}$ & & -0.10 & 0.42 & -0.35 & -0.10 & -0.11 & -0.17 & -0.22 & -0.04 & 0.02 & -0.19 & 0.16 \\
\hline MAX $^{3}$ & & & 0.05 & -0.45 & -0.06 & 0.16 & -0.23 & 0.26 & -0.25 & -0.02 & -0.09 & 0.31 \\
\hline $\mathrm{DD}^{4}$ & & & & 0.19 & $0.51^{*}$ & -0.08 & 0.45 & -0.24 & -0.28 & $-0.56^{*}$ & $0.51^{*}$ & 0.09 \\
\hline RAIN $^{5}$ & & & & & 0.30 & -0.23 & 0.47 & -0.11 & -0.02 & -0.10 & 0.42 & -0.45 \\
\hline $\mathrm{LENG}^{6}$ & & & & & & 0.22 & $0.96^{*}$ & $-0.58^{*}$ & $-0.56^{*}$ & $-0.50 *$ & $0.87^{*}$ & 0.36 \\
\hline $\mathrm{WID}^{7}$ & & & & & & & 0.14 & -0.01 & -0.13 & -0.41 & 0.26 & 0.31 \\
\hline THICK $^{8}$ & & & & & & & & $-0.62 *$ & 0.48 & $-0.52 *$ & $0.90 *$ & 0.24 \\
\hline NUM $^{9}$ & & & & & & & & & 0.09 & 0.21 & -0.45 & -0.18 \\
\hline $\mathrm{FM}^{10}$ & & & & & & & & & & 0.26 & -0.43 & 0.18 \\
\hline $\mathrm{DM}^{11}$ & & & & & & & & & & & $-0.75^{*}$ & 0.22 \\
\hline $\mathrm{WC}^{12}$ & & & & & & & & & & & & 0.16 \\
\hline
\end{tabular}

${ }^{1} \mathrm{CYCLE}=$ maturation cycle $;{ }^{2} \mathrm{MIN}=$ minimum temperature; ${ }^{3} \mathrm{MAX}=$ maximum temperature $;{ }^{4} \mathrm{DD}=$ degrees-day $;{ }^{5} \mathrm{RAIN}=$ accumulated rain; ${ }^{6} \mathrm{LENG}=$ length; ${ }^{7} \mathrm{WID}=$ width; ${ }^{8} \mathrm{THICK}=$ thickness; ${ }^{\mathrm{N} U M}=$ number of seeds per fruit; ${ }^{10} \mathrm{FM}=$ fresh mass; ${ }^{11} \mathrm{DM}=$ dry mass; ${ }^{12} \mathrm{WC}=$ water $\operatorname{content} ;{ }^{13} \mathrm{G}=$ germination. $(*)=$ $\mathrm{r}$ significant at $5 \%$ probability, without asterisk $=$ non significant correlations.

It was observed also that the origins that were similar in length, width and thickness, for example, RIB, CAM1, CAM2, JUM, SBC1, SBC2 and IBI1 showed as well similar values as the sum of degree-days (Tables 1 and 2). The differences between seed sizes were also observed for samples taken at the same plants, but at different periods (SBS and IBI); however, they were more evident concerning the fresh and dry mass content (SBS, IBI and SBC). Despite the differences in dimensions, seeds from only three regions showed germination values below the highest LAV (100\%), namely, SPA1 (63\%), IBI2 (57\%) and SBC1 (68\%) (Table 2).

In studies of Tabebuia chrysotricha seeds, arising from the same population (Santos et al., 2009), but from different plants and with Eugenia dysenterica seeds (Silva et al., 2001) and Eugenia calycina (Cardoso and Lomônaco, 2003), from different populations, variations in the biometric of seeds were observed, which have also been associated, among other factors, to phenotypic differences in response to environmental conditions. In this study, the biometric variations of uvaia seeds from different regions and periods were correlated with 
environmental conditions, specifically among accumulated degree-days and length, dry mass content and water content variables (Table 3 ).

The maturation cycle also exerted influence on the biometric variables (length, thickness, dry mass content and water content), with significant correlations (Table 3). This cycle, however, was positively correlated with accumulated rainfall and degree-days. The influence of environmental conditions on seed maturity and physical characteristics has also been demonstrated for Aesculus hippocastanum and Acer pseudoplatanus (Daws et al., 2004, 2006), coffee (Petek et al., 2009), Euterpe edulis (Martins et al., 2009), Quercus ilex (Joët et al., 2013) and Inga vera (Lamarca et al., 2013c), besides the uvaia itself (Lamarca et al., 2013a).

The results of germination of cut seeds of different sizes and origins (seed number per fruit) as well as the seed biometric variations from different regions and seasons, allow its division into three groups. In the first one, with greater chances of success in obtaining seedlings from cut seeds, they would include the ones coming from SBS, LAV, PAR, JUM, ITA and RIB; in the second one, with higher probability of failure, SPA and IBI; in the third one, CAM and SBC seeds, in borderline position between success and failure, being more dependent on the number of seeds per fruit and environmental conditions, according to the year of seed production. Therefore, although one can get technological gain by cutting uvaia seeds for seedling production, reaching a $50 \%$ increase as shown in previous works (Silva et al., 2003), it became clear that this gain depends on a previous analysis of the lot biometric characteristics, which may vary according to the region and the season.

\section{Conclusions}

The ability to produce new seedlings in uvaia seeds after cutting depends on the seed size, which also depends on the number of seeds per fruit, the region and the period of the seed production.

\section{Acknowledgments}

The authors wish to thank Dr. Domingos S. Rodrigues (IBt), Dr. João J. D. Parisi (IAC), the Regional Pole of Vale do Ribeira - Pariquera-Açú/São Paulo, CATI from Itaberá/SP, CATI from São Bento do Sapucaí/São Paulo, the Agriculture House in Jumirim/São Paulo, USP-University of Ribeirão Preto/ São Paulo, the Botany Institute of São Paulo/SP, the Agronomic Institute of Campinas/São Paulo, the Lavras Federal University/ Minas Gerais, Mrs. Kathya I. B. Costa and Mr. Milton R. Costa, for permission and support in collections; Dr. Lucia Rossi (IBt), for the species identification; the Lavras Federal University, Lavras, Minas Gerais, the Agronomic Institute of Campinas, Campinas/São Paulo and the Astronomical and Geophysical Institute of the University of São Paulo, São Paulo/SP, for the provision of meteorological data; the CNPq and CAPES for scholarships granted to J.S. Prataviera (Scientific Initiation), E.V. Lamarca and C.C. Teixeira (Doctorate) and C.J. Barbedo (Research Productivity).

\section{References}

AMADOR, T.S.; BARBEDO, C.J. Potencial de inibição da regeneração de raízes e plântulas em sementes germinantes de Eugenia pyriformis. Pesquisa Agropecuária Brasileira, v.46, p. 814-821, 2011. http://www.scielo.br/pdf/ $\mathrm{pab} / \mathrm{v} 46 \mathrm{n} 8 / 05 . \mathrm{pdf}$

ANDRADE, R.N.B.; FERREIRA, A.G. Germinação e armazenamento de sementes de uvaia (Eugenia pyriformis Camb.) - Myrtaceae. Revista Brasileira de Sementes, v.22, n.2, p.118-125, 2000. http://hdl.handle. net/10183/23264

ANDRADE, L.A.; BRUNO, R.L.A.; SOARES, L.; OLIVEIRA, B.; SILVA, H.T.F. Aspectos biométricos de frutos e sementes, grau de umidade e superação de dormência de jatobá. Acta Scientiarum Agronomy, v.32, p.293299, 2010. http://www.scielo.br/pdf/asagr/v32n2/a16v32n2.pdf

BATYGINA, T.B.; VINOGRADOVA, G.Y. Phenomenon of polyembryony. Genetic heterogenity of seeds. Russian Journal of Developmental Biology, v.38, p.126-151, 2007.http://download.springer. $\mathrm{com} / \mathrm{static} / \mathrm{pdf} / 882 / \mathrm{art} \% 253 \mathrm{~A} 10.1134 \% 252 \mathrm{FS} 1062360407030022$. pdf?auth66=1419268241_9f33377ab9ce09346fd271c5311779c0\&ext=.pdf

BRASIL. Ministério da Agricultura, Pecuária e Abastecimento. Regras para análise de sementes. Ministério da Agricultura, Pecuária e Abastecimento. Secretaria de Defesa Agropecuária. Brasília: MAPA/ACS, 2009. 395p. http:// www.agricultura.gov.br/arq_editor/file/2946_regras_analise_sementes.pdf.

CARDOSO, G.L.; LOMÔNACO, C. Variações fenotípicas e potencial plástico de Eugenia calycina Cambess. (Myrtaceae) em uma área de transição cerrado-vereda. Revista Brasileira de Botânica, v.26, p.131-140, 2003. http:// www.scielo.br/pdf/rbb/v26n1/v26n1a14.pdf

DAWS, M.I.; LYDALL, E.; CHMIELARZ, P.; LEPRINCE, O.; MATTHEWS, S.; THANOS, C.A.; PRITCHARD, H.W. Developmental heat sum influences recalcitrant seed traits in Aesculus hippocastanum across Europe. New Phytologist, v.162, p.157-166, 2004. http://onlinelibrary.wiley. $\mathrm{com} /$ doi/10.1111/j.1469-8137.2004.01012.x/pdf

DAWS, M.I.; CLELAND, H.; CHMIELARZ, P.; GORIN, F.; LEPRINCE, O.; MATTHEWS, S.; MULLINS, C.E.; THANOS, C.A.; VANDVIK, V.; PRITCHARD, H.W. Variable dessication tolerance in Acer pseudoplatanus seeds in relation to developmental conditions: a case of phenotypic recalcitrance? Functional Plant Biology, v.33, p.59-66, 2006. http://dx.doi. org/10.1071/FP04206

DELGADO, L.F., BARBEDO, C.J. Tolerância à dessecação de sementes de espécies de Eugenia. Pesquisa Agropecuária Brasileira, v.42, p.265-272, 2007. http://www.scielo.br/pdf/pab/v42n2/16.pdf

DELGADO, L.F.; MELLO, J.I.O.; BARBEDO, C.J. Potential for regeneration and propagation from cut seeds of Eugenia (Myrtaceae) tropical tree species. Seed Science and Technology, v.38, p.624-34, 2010.http:// dx.doi.org/10.15258/sst.2010.38.3.10 
JOËT, T.; OURCIVAL, J. M.; DUSSERT, S. Ecological significance of seed desiccation sensitivity in Quercus ilex. Annals of Botany, v.111, p.693-701, 2013. http://aob.oxfordjournals.org/content/early/2013/02/05/aob.mct025.full.pdf

JUSTO, C.F.; ALVARENGA, A.A.; ALVES, E.; GUIMARÃES, R.M.; STRASSBURG, R.S. Efeito da secagem, do armazenamento e da germinação sobre a micromorfologia de sementes de Eugenia pyriformis Camb. Acta Botanica Brasilica, v.21, p.539-551, 2007. http://www.scielo.br/pdf/abb/ v2 1 n3/a04v21n3.pdf

LAMARCA, E.V.; BAPTISTA, W.; RODRIGUES, D.S.; OLIVEIRA JUNIOR, C.J.F. Contribuições do conhecimento local sobre o uso de Eugenia spp. em sistemas de policultivos e agroflorestais. Revista Brasileira de Agroecologia, v.8, p.119-130, 2013a. http://www.aba-agroecologia.org.br/ revistas/index.php/rbagroecologia/article/view/13256/9905

LAMARCA, E.V.; PRATAVIERA, J.S.; BORGES, I.F.; DELGADO, L.F.; TEIXEIRA, C.C.; CAMARGO, M.B.P.; FARIA, J.M.R.; BARBEDO, C.J. Maturation of Eugenia pyriformis seeds under different hydric and thermal conditions. Anais da Academia Brasileira de Ciências, v.85, p.223-233, 2013b. http://www.scielo.br/pdf/aabc/v85n1/0001-3765-aabc-85-01-223.pdf

LAMARCA, E.V.; BONJOVANI, M.R.; FARIA, J.M.R.; BARBEDO, C.J. Germinação em temperatura sub-ótima de embriões de Inga vera subsp. Affinis obtidos sob diferentes condições ambientais. Rodriguésia, v.64, p.877-885, 2013c. http://www.scielo.br/pdf/rod/v64n4/v64n4a15.pdf

MARCOS-FILHO, J. Fisiologia de sementes de plantas cultivadas. Piracicaba: FEALQ, 2005. 495p.

MARTINS, C.C.; BOVI, M.L.A.; NAKAGAWA, J.; MACHADO, C.G. Secagem e armazenamento de sementes de juçara. Revista Árvore, v.33, p.635-642, 2009. http://www.scielo.br/pdf/rarv/v33n4/v33n4a06.pdf

PEDRO JUNIOR, M.J.; BRUNINI, O.; ALFONSI, R.R.; ANGELOCCI, L.R. Estimativa de graus-dia em função de altitude e latitude para o estado de São Paulo. Bragantia, v.36, p.89-92, 1977. http://www.scielo.br/pdf/brag/v36n1/05.pdf

PETEK, M.R.; SERA, T.; FONSECA, I.C.B. Exigências climáticas para o desenvolvimento e maturação dos frutos de cultivares de Coffea arabica. Bragantia, v.68, p.169-181, 2009. http://www.scielo.br/pdf/brag/v68n1/ a18v68n1.pdf

RAMIREZ, M.R.; SCHNORR, C.E.; FEISTAUER, L.B.; APEL, M.; HENRIQUES, A.T.; MOREIRA, J.C.F.; ZUANAZZI, J.A.S. Evaluation of the polyphenolic content, anti-inflammatory and antioxidant activities of total extract from Eugenia pyriformes Cambess (uvaia) fruits. Journal of Food Biochemistry, v.36, p.405-412, 2012. http://onlinelibrary.wiley.com/ doi/10.1111/j.1745-4514.2011.00558.x/pdf
SANTANA, D.G.; RANAL, M.A. Análise da germinação: um enfoque estatístico. Brasília: Universidade de Brasília, 2004. 248p.

SANTOS, F.S.; PAULA, R.C.; SABONARO, D.Z.; VALADARES, J. Biometria e qualidade fisiológica de sementes de diferentes matrizes de Tabebuia chrysotricha (Mart. ex A. DC.) StandI. Scientia Forestalis, v.37, p.163-173, 2009. http://www.ipef.br/publicacoes/scientia/nr82/cap06.pdf

SILVA, R.S.M.; CHAVES, L.J.; NAVES, R.V. Caracterização de frutos e árvores de cagaita (Eugenia dysenterica DC.) no sudeste do estado de Goiás, Brasil. Revista Brasileira de Fruticultura, v.23, p.330-334, 2001. http://www. scielo.br/pdf/rbf/v23n2/7976.pdf

SILVA, C.V.; BILIA, D.A.C.; MALUF, A.M.; BARBEDO, C.J Fracionamento e germinação de sementes de uvaia (Eugenia pyriformis Cambess.- Myrtaceae). Revista Brasileira de Botânica, v.26, p.213-221, 2003.http://www.scielo.br/pdf/rbb/v26n2/a09v26n2.pdf

SILVA, C.V.; BILIA, A.C.; BARBEDO, C.J. Fracionamento e germinação de sementes de Eugenia. Revista Brasileira de Sementes, v.27, p.86-92, 2005. http://www.scielo.br/pdf/rbs/v27n1/25185.pdf

STIEVEN, A.C.; MOREIRA, J.J.; SILVA, C.F. Óleos essenciais de uvaia (Eugenia pyriformis Cambess): avaliação das atividades microbiana e antioxidante. Eclética Química, v.34, p.7-13, 2009. http://www.scielo.br/pdf/ eq/v34n3/01.pdf

TEIXEIRA, C.C., BARBEDO, C.J. The development of seedlings from fragments of monoembryonic seeds as an important survival strategy for Eugenia (Myrtaceae) tree species. Trees, v.26, p.1069-1077, 2012. http://download springer.com/static/pdf/86/art\%253A10.1007\%252Fs00468-011-0648-5. pdf?auth66=1419267966 7e6742fd8463ea9746b548039f7dc051\&ext=.pdf

VILLA NOVA, N.A.; PEDRO JÚNIOR, M.J.; PEREIRA, A.R.; OMETTO, J.C. Estimativa de graus-dia acumulados acima de qualquer temperatura base em função das temperaturas máxima e mínima. Caderno Ciência da Terra v.30, p.1-8, 1972. 